\title{
A Critical Analysis of Refugee Protection in South Asia
}

\author{
Veerabhadran Vijayakumar
}

\begin{abstract}
Many countries in Asia and all the countries in South Asia have not acceded to the Refugee Convention of 1951 or the Protocol of 1967 in spite of the fact that a large number of refugees come from this region. The reasons for not ratifying them are not clear even though many international human rights instruments have been ratified by many of them. The probable reasons for not ratifying the Refugee Convention or the Protocol, the lack of any regional approach or national legislation to address the problem, the contribution made by the international community to the crises in this region, nature of protection, the extent of rights available to the refugees and a brief comparison between the Northern and Southern perspectives have also been explained. Some of the important judicial decisions from India have been relied upon to appreciate the developments. This article concludes by emphasizing that through a comparative analysis of both the Northern and Southern perspectives relating to the protection of refugees, each can benefit from the experiences of the other, improve and build a scheme to care for the millions of refugees as well as others of concern in the new millennium.
\end{abstract}

\section{Résumé}

Beaucoupdepaysd'Asieengénérale, ettous les pays de l'Asie du Sud en particulier, n'ontpas adhéréà la Convention de 1951 relative au statut des réfugiés ou au Protocole de 1967, en dépit du faitqu'un groscontingentde réfugiésprovientdecette région. Lesraisons pourcettenon-ratification ne sont pas claires, alors même que beaucoupdeces paysont ratifiéplusieurs

Dr.V.Vijayakumar, a Visiting Scholar at the Centre for Refugee Studies during 2000, is a Professor of Lawat the National Law School of India University (NLSIU), Bangalore, India andalsoadministersthe Chairon Refugee Law endowed by the UNHCR. instruments internationaux dans le domaine des droits de l'homme. Sont expliquéesiciles raisonsprobablespourla non-ratification de la Convention surles réfugiés ou le Protocole, l'absence totale d'uneapprocherégionaleou delégislation nationalepourréglerleproblème, lacontribution faite par la communauté internationale pour régler les crises dela région, la nature dela protection, l'étendue des droits consentis aux réfugiés, ainsi qu'unebrèvecomparaisonentrelesperspectives Nond-Sudsurcesquestions. Pourfaire l'appréciation de ces développements, l'article s'appuie sur certaines décisions juridiques importantes del'Inde. L'article conclutensoulignantlefaitqu'àtraversune analysecomparativedesperspectives Nord -Sudconcernantlaprotection des réfugiés, chacun peuttirerprofit del'expériencede l'autre, améliorer et bâtir un projet pour s'occuperdesmillionsderéfugiés, aussibien qued'autres personnes à risque, dans le nouveaumillénaire.

Many of the countries in Asia in general have not ratified the 1951 Refugee Convention or the 1967 Protocol due to one reason or the other. Within Asia, the countries in the South Asian region that witnessed the largest of the population movements over the last 50 to 55 years have not become parties to the international instruments relating to refugees. The developments regarding the population movements in this South Asian region, their status, nature of protection and the like are discussed in this paper briefly in an attempt to compare the same with the developments taking place in the West. However, towards the end, frequent reference to the developments in India is made to substantiate the views.

The term 'South Asia' is used in the context of a group of nations consisting of Bangladesh, Bhutan, India, Maldives, Nepal, Pakistan and Sri Lanka. This group of seven nations also has a regional organization called the South
Asian Association for Regional Cooperation (SAARC). None of the seven countries in this region is a party to the 1951 Convention or the 1967 Protocol relating to the Status of Refugees. However, these countries have ratified some of the human rights instruments in the recent past. All these seven countries have ratified the International Convention on the Elimination of All Forms of Racial Discrimination, 1969, the Convention on the Rights of the Child, 1989 and the Convention on the Elimination of All Forms of Discrimination Against Women, 1981. All of them have ratified the four Geneva Conventions as well. In relation to other human rights instruments, some of them have ratified a few more and some are in the process of ratifying them. A large part of this region was under foreign rule for a long time before independence was given to them after the World War II. The reasons for not acceding to the international instruments relating to refugees, the extent of refugee problems in the region, status determination, the nature of protection, refugee rights, the role of western countries to refugee problems in this region, the role of UNHCR and other institutions as well as the prospect for developing a legal regime relating to the refugees in this region are discussed briefly.

\section{Reasons for not Aceding to the Refugee Convention}

There seems to be no official document to indicate or explain the reasons for not ratifying the Refugee Convention or the Protocol. However, various writers have indicated the reasons for this behaviour based on their knowledge and expertise in this region. Many other opinions have been expressed by the officials in the respective ministry on this issue and as such cannot be quoted with authority. This has allowed the critics the freedom to infer the reasons for not signing these two international instruments, based on their own under- 
standing and circumstances. Apart from the sources that can be quoted authoritatively, the rest of the reasons are at best only inferences that can be drawn from the past behaviours and practices. Some of the reasons would include the following.

The first and the foremost reason that can be given is the non-acceptance of a broader definition of refugees as advanced by India and Pakistan by the international community. In a debate on the successor to the International Refugee Organization (IRO), both India and Pakistan strongly recommended for acceptance, a liberal meaning for the term 'refugees' so as to include the 'internal refugees' as well. ${ }^{1}$ However, it was not accepted and a restrictive meaning was accepted. After this, there has been a negative attitude developed towards the Refugee Convention by both countries.

The second reason is based on this continuum. Both India and Pakistan have been advancing the argument that the refugee definition is very narrow as well as Euro-centric and that it would not serve the objectives in the South Asian context.

In the third place, the countries in the South Asian region have placed reliance on a 'bilateral approach' rather than 'multilateral approach' in their policies to resolve their conflicts, including the policies on 'population displacement' and 'refugees'. The line of argument taken by them seems to suggest that by internationalizing the refugee issues, there is more scope for international criticism resulting in unnecessary interference in internal matters of the countries concerned. This phenomenon is also explained in terms of reluctance on the part of the states to cede their policy-making autonomy to an outside authority. ${ }^{2}$ The countries in this region have given their highest priority to the concept of national sovereignty and as such they usually frown at any type of intervention in their internal affairs. Explaining the concept of burden sharing, Amitav Acharya and David B. Dewitt have observed that the governments in the Third World are extremely sensitive to the fact that humanitarian operations, even by suppos- edly neutral multilateral organizations, are a violation of sovereignty and constitute an unacceptable interference in their internal affairs.' ${ }^{3}$ The solutions taken in the cases of Chakma refugees, Rohinga refugees and the ongoing dialogue between Nepal and Bhutan in resolving the Bhutanese refugee problem indicate unshakable faith the states in this region have in resolving their conflicts through bilateral negotiations of the parties concerned.

In the fourth place, the states in this region allege that even the states that have ratified the Convention or the Protocol are not following the provisions effectively and as such would not be beneficial to the countries in the South Asian region to ratify them now. These countries also fear that they would be obliged to take additional burdens and responsibilities when these two instruments are ratified. While there may be some truth in their analysis, there are states that have taken the Convention and the Protocol seriously and have evolved better norms in the protection of the refugees. However, these developments seem to have no positive impact on the countries in the South Asian region yet.

The nextreason advocated by some of the countries in the South Asian region is that the Convention and the Protocol have not addressed the larger issues relating to 'security' and as such the provisions are being invoked by economic migrants, terrorists and other groups of forced migrations.

In the next place, the argument that the office of the United Nations High Commissioner for Refugees is not a permanent one as the life of the organization is periodically being extended from time to time, depending upon the circumstances. ${ }^{4}$ That being the case, why should the instruments be acceded to if there is no specific guarantee as to its existence in the future, seems to be the logical conclusion. However, this argument focuses on a technical aspect and skips the substantive part of it.

The seventh reason is based on the sixth one. The states in this region argue that there is going to be no 'material improvement' by signing the Conven- tion or the Protocol relating to refugees. However, what they really mean by material improvement is not clear. The predominant apprehension may be that by acceding to the instruments, the South Asian region would still continue to face all the issues relating to the refugees (probably in terms of finding durable solutions or finding a meaningful international burden sharing).

In the next place, there is bureaucratic insensitivity coupled with the lack of political will that seems to be the dominating practical reason in the South Asian region. Whenever questions relating to the accession of these two instruments are raised, there is astonishingly a uniform response given that it is not in the priority list of the state. Justice V.R.Krishna Iyer, former judge of the Indian Supreme Court, had observed in this regard that 'India should be a member state and play a role by being on the Executive Committee of the High Commissioner's programme. To waver or wobble or vacillate when moral values dictate, is bankruptcy of leadership. Let us not fail humanity, especially that sector which is desparate, driven out and wanders homeless in the world for sheer survival. ${ }^{5}$

This naturally leads to the next reason that when there are appropriate and suitable statutes to deal with the refugees present in the states, why should they think in terms of enacting a statute afresh to give effect to international obligations to be undertaken? As some of the countries remained the colonies under foreign rule for quite some time, these states would like to have the continued benefit of the existing preindependent statutes that give them more powers to deal with the situations than passing a statute afresh and to be subjected to the scrutiny of the international community. It becomes convenient for the states to follow the already existing pre-independent statutes like Foreigners Act, the Registration of Foreigners Act and the Passport Act that give them more and more discretionary powers. Vitit Muntarbhorn has effectively advanced the same view with reference to Asia. According to him ' [a] 
constant dilemma facing the Asian region is the conflict between international and national perceptions of the refugee problem. The governments confronted with an undesired influx of asylum seekers may choose to ignore international refugee law as a matter of expediency, thereby using local immigration law and terminology to constrain such influx' ${ }^{6}$ The same is true with the countries in the South Asian region as well.

In the next place, the argument targets the nature of 'international burden sharing' stating that it is neither effective nor meaningful. The largest movements of population so far in the world have taken place within this South Asian region that have been met with a very poor response by international community. Timely assistance was also not forthcoming during the crisis in this region. ${ }^{7}$ This seems to be the more justifiable reason when compared with the other reasons given above.

In the next place, linking population movements with the concern for the growth of the regional organization have also contributed to ignoring the accession of these two instruments. Myron Weiner has observed that 'porous borders and cross-border population movements in South Asia are regarded as issues that affect internal security, political stability and international relations, not simply the structure and composition of labour market, or the provisions of services to newcomers and advanced the reason for not taking up the issues relating to migration in the region'. He went on to observe that 'in the circumstances the states in the region do not want to deal with the issues concerned through multilateral channels. Indicative of the desire to deal bilaterally with the entire gamut of problems is the fact that the paramount regional organization, the South Asian Association for Regional Cooperation (SAARC), has chosen to exclude the issue of population movement from its purview for fear that it would disrupt the organization. ${ }^{8}$

Another important argument against the accession to the RefugeeConvention and the Protocol is that it would lead to the establishment of a number of administrative and quasi-judicial bodies for status determination and that involves enormous expenditure from the state exchequer. As the states in the region are all developing countries, they cannot afford to spend huge sums of money in the process of status determination as well as other related areas.

Finally, the states in the South Asian region also argue that group or category based determination has not been given importance under the Convention or the Protocol. So far the countries in this region have placed greater reliance on this group or category approach to determine the status of refugees as such, an approach that allows the retention of a final say with the respective governments. The individual status determination is not at all followed as the government in power at the centre would like to have the discretionary power as well as a greater say in either accepting or rejecting the refugees as a single group. The reasons mentioned here are not exhaustive and are based on inferences drawn from various sources.

\section{The Nature of Refugee Movements in this Region}

The following paragraphs focus on the major refugee movements that have occurred since 1947 as well as the contemporary refugee issues in this region. For the purposes of appreciating these issues better, the presence of refugee crisis in the South Asian region is divided into two broad categories. The first category includes the refugee movements within the region, from one country to another in the region. The second category would include those movements of refugees from countries outside the region to the countries within the South Asian region. This region has witnessed a number of refugee movements both from within the region as well as from outside the region. About $12.04 \%$ of the global refugee population continue to remain in this region. ${ }^{9}$ According to the statistics provided by the U.S Committee for Refugees, $12.02 \%$ of the total refugee population lives in Bangladesh, India, Nepal and Pakistan. ${ }^{10}$ Some of the refugee movements are mentioned here in brief.
(A) Refugee Movements within South Asia

When the British left India in 1947, they divided the country to establish two independent Dominions, i.e. India and Pakistan. Because of this there was a natural flow of Muslims towards East and West Pakistan and the Hindus towards India. An estimated 15 to 20 million people who were persecuted or had the fear of being persecuted left their properties, trade and business behind in an attempt to cross the newly established borders. In the establishment of two Dominions, Pakistan had two territories, the West and the East that itself had become the reason for further flow of refugees at a latter point of time. However, these people who were called refugees, evacuees, migrants and displaced persons by various orders, rules, regulations and statutes passed in India and Pakistan, quickly got settled with the series of efforts taken by the respectivegovernments.

A large section of people of Indian origin (Tamils) taken to SriLanka by the British and employed in tea estates and other agricultural activities for generations were rendered 'stateless' with the introduction of the Citizenship Acts in 1948 and 1949 in Sri Lanka. Various agreements between India and Sri Lanka resulted in India taking about 338,000 stateless persons for settlement and rehabilitation during 1964-1987. ${ }^{11}$ Apart from this, there have been three major refugee flows from Sri Lanka into the province of Tamil Nadu, in southern India from 1983. This flow of Sri Lankan refugees continues even today. These refugees are housed in 136 camps established by the state and in 1990 an estimated 120,000 Sri Lankan refugees were present in these camps. Apart from them more than 80,000 'well to do' (rich) refugees were living outside the camps. ${ }^{12}$ These refugees were not registered earlier and the number of refugees staying outside the camps is much higher than what is indicated in the reports. According to the U.S Committee for Refugees, there are $110,000 \mathrm{Sri}$ Lankan Tamil refugees in the State of Tamil Nadu. ${ }^{13}$ During 1990, a Special 
Commissioner was appointed by the Government of Tamil Nadu as the state had an average expenditure of about Rupees 30 crores (approximately 26 million U.S \$ per annum). ${ }^{14}$ Recent developments in Sri Lanka are likely to lead to further flows of refugees into India.

The Chakma refugees, the tribal groups of Chittagong Hill Tracts (CHT) consisting of Chakmas, Murangs and Tripuras migrated to the territories of Assam, Tripura, Arunachal Pradesh, Mizoram and Meghalaya after the partition in 1947. During 1963, about 45,000 Chakmas fled to India from East Pakistan as victims of the Kaptai Hydro electric project that inundated their homelands. They multiplied and their numbers swelled to 85,000. ${ }^{15}$ After the liberation of Bangladesh, erstwhile East Pakistan, about 50,000 refugees have been repatriated back to $\mathrm{CHT}$ last year i.e. in 1998.

Between April 1 and mid October 1971 , a total of $9,544,012$ officially recorded refugees from East Pakistan moved into India. This flow of refugees into India is unparalleled in modern history. ${ }^{16}$ These refugees continued to stay in India until 1973 and many refugees have stayed back in India with their friends and relatives. Predominantly, these were from the 2-3 million refugees living with the relatives and friends in the State of West Bengal. ${ }^{17}$ The language they speak acted as a facilitator for such local assimilation without being identified as foreigners by any one. The number of people who stayed back without being identified by the authorities for repatriation is very high. The process of repatriation of these refugees back to the newly established state of Bangladesh was in fact very quick and encouraging for the host country. According to the UNHCR, a daily average of 210,000 persons crossed the Bangladesh border from India in the process of repatriation during the months of January and February 1972. All these refugees were returning from India to their native places in East Bengal. ${ }^{18}$

About 125,000 Bhutanese of Nepali origin were forced to leave Bhutan by the actions taken by the Government of Bhutan including the passing of the Citizenship Act. These people are now settled in about 7 camps in Southern Nepal. India also hosts some of them. ${ }^{19}$ Apart from these refugees, an estimated 40,000 Chin/Arakanese refugees from Burma and ten million illegal immigrants are also present in India today. ${ }^{20}$

\section{(B)Refugees from Outside the South Asian Region}

When Burma (now Myanmar) was granted independence by the British in 1948, a large number of people of Indian origin were pushed out. These people who migrated to Burma under British patronage and settled there had no option but to return to India as refugees. Burma again sent refugees to India after political changes in 1962. An estimated 150,000 refugees came to India during that period. As many as 200,000 Rohingya refugees sought asylum in Bangladesh as a result of the Burmese army's operations in the Arakan region during 1978 in an attempt to check illegal migrants and fight insurgency. There was a second flow of refugees into Bangladesh and by 1992 there were 300,000 refugees. However, an agreement between Bangladesh and Burma resulted in repatriation process for sometime. Yet these refugees continue to stay in Bangladesh ${ }^{21}$ as well as in India.

In 1959, the Dalai Lama, a religious and political leader and his followers fled Tibet and came to India seeking asylum. Asylum was granted to them by the then Prime Minister of India, Mr.Jawaharlal Nehru, and these Tibetan refugees continue to stay in India even today. By 1993, there were 133,000 Tibetan refugees in South Asia out of which India alone hosts about 120,000 of them in 42 settlements spread over different provinces in India. Apart from the settlements there are also 88 scattered communities in different parts of India. ${ }^{22}$ There has been a steady flow of Tibetan refugees into India through Nepal during the recent past as well. Thecontinued presence of these Tibetan refugees in India over the past forty years seems to be undermining the con- cept of temporary asylum. In contrast, the concept of temporary protection is understood as a protection for a limited period of time in the developed coun. tries until a durable solution is found.

The existence of the cold war period coupled with the Soviet Union's invasion of Afghanistan in 1979 resulted in a large-scale migration of the Afghans into Pakistan. Prior to this, there were movements of the Afghans into Pakistan after the coup in 1973. The subsequent civil war kept the problem alive and as a net result of these developments, an estimated 6 million Afghans were uprooted. With the withdrawal of Russianforces, the repatriation process took place. ${ }^{23}$ However, the continued infighting kept the problem alive and Pakistan has about 1,200,000 Afghan refugees even today. India also hosted about 40,000 Afghan refugees, their status being determined by the UNHCR. However, their number has come down to 18,607 and majority of them live in the New Delhi area. By the end of 1998, there were still 14,500 Afghan refugees living in India. ${ }^{24}$

There are also other refugees from the African countries as well as West Asia, but in small numbers. Many of them are recognized by the UNHCR's office in India as refugees and some of them are living there in the same status for more than 10 years. These refugee movements only indicate the gravity of the problem with very little attention given by the countries in this region.

\section{Refugee Protection in South Asia}

Whenever a mass exodus takes place necessitating immediate and elaborate arrangements, the countries in South Asia have responded positively in according refugee status to all and in providing the basic necessities within the economic means of the receiving state concerned. South Asia as a whole has extended protection to refugees for a long period of time and has been extremely tolerant of the incoming population with a different culture, language or race. The protection extended to the hundreds and thousands of Afghan refugees and the continued assistance for the remaining Afghans in Pakistan 
is an example of this protection. India's decision to accord refugee status to the Tibetans fleeingChina in 1959 and their continued presence even after 40 years is another example for South Asia's contribution to refugee protection. Again the movement of $\mathbf{1 0}$ million refugees from erstwhile East Pakistan into India, the largest refugee influx the world has seen so far, met with the same positive approach to the sufferings of the people. The protection extended by Bangladesh to the Rohingya refugees from Myanmar, the protection extended by Nepal to the Lhotsampa refugees (from Bhu$\tan$ ) and the protection extended by India to Sri Lankan Tamils are the other examples of the nature of protection extended to the refugees over a period of time. In doing so, the judiciary as well as the administration in these countries have directly or indirectly recognized the principles of international refugee law and have adhered to them although the states have not become parties to the relevant international instruments. The people in these countries deserve specific appreciation for having been not only tolerant but also contributing to the meaningful protection within their economic means.

These factors have contributed to the presence of at least three members from this region on the Executive Committee of the UNHCR. Pakistan, Bangladesh and India have become active members of the EXCOM of the UNHCR even without being parties to the international instruments. This is indicative of the appreciation by the international community for the nature of initiatives taken by them over a period of time. In the same continuum, all the seven countries in the region have allowed the office of UNHCR to work closely with the respective governments. UNHCR has established its offices in many of the countries in South Asia and in a couple of states it operates from the offices close by. Thus the countries have permitted the UNHCR to exercise its mandate in their respective territories and have tacitly approved the mandate refugees. However, this optimism is to be read and understood with some amount of caution.
In this analysis of the nature of protection extended by the countries in the South Asian region to the refugees, mention must be made to the Tibetan refugees in India. They are treated well, compared to all other refugees in this region. The extent of the rights and freedom extended to them are explained in this article subsequently. A number of human rights instruments ratified by the countries in the South Asian region have also contributed to the positive initiatives taken by them from time to time. The role played by international politics in this region has also contributed to these measures taken by the states in protecting the refugees with in the limited resources they possess.

\section{The Determination of Refugee Status}

Countries in the South Asian region have not established any administrative or quasi-judicial bodies to determine the status of refugees. Broadly speaking, there are four types of determination of refugee status that take place in this region. These procedures are explained here briefly.

\section{Group Determination}

All the refugee-receiving states in this region have resorted to this group determination of the refugee status to a large extent. By and large they have followed the mandate of the UNHCR as provided in the Statute of the UNHCR. ${ }^{25}$ In the movement of the Rohingya refugees from Burma, during 1978, an estimated five to ten thousand refugees were crossing the border each day. ${ }^{26}$ During another movement of the same refugees in 1992, the UNHCR Technical Mission reported that the refugees were streaming into the country (Bangladesh) at a rate of thousand a day. ${ }^{27}$ The movement of large numbers of refugees in to these countries from time to time can not be managed in any other way than by the group determination of their status. In the absence of any mechanism to determine the status of refugees, states have placed greater reliance on this procedure. Almost all the refugee movements in this region required immediate acceptance by the receiving states, giving very little time to think about any other alternative. When the Tibetan refugees sought asylum during 1959 in India, it was a large group. When the East Pakistani refugees started moving into India, it was the largest movement of refugee population that has taken place in the human history so far. At one point of time, there was an average daily influx of about 97,821 refugees moving into India during May $1971 .^{28} \mathrm{~A}$ large number of refugees came to India in 1983 onwards from Sri Lanka. During July 1990 , about 2000 to 3000 Sri Lankan refugees arrived per day in Tamil Nadu. ${ }^{29}$ Pakistan and Bangladesh also faced similar situations in accepting the Afghan refugees and the Rohingya refugees from Myanmar respectively.

These countries cannot evén think of establishing independent administrative or quasi-judicial bodies to determine the status of each and every refugee like the developed countries. When it is very difficult for them to look after the refugees within their financial resources, the establishment of such authorities to determine the status of refugees cannot be even thought of. The lack of political will to think on these lines in establishing appropriate machinery coupled with 'bureaucratic caution', probably, strengthened the group determination procedure in this region. The determination of the status of refugees in this manner provided the policy makers with the ultimate decision-making power. Moreover, such decisions cannot be questioned in any court of law, in the absence of any refugee specific legislation. As it gave the governments unquestionable and arbitrary decision making power, more reliance was placed on this group determination of refugee status in this region.

\section{Determination of Status by the UNHCR}

In a few cases where large numbers of people were not involved and at the same time the country concerned is not willing to involve itself politically in the determination of the status of refugees, they have permitted the UNHCR to de- 
termine their status individually. However, such decisions gave only limited powers to the UNHCR. For example, the decision of the Government of India in allowing the UNHCR's office in New Delhi to determine the status of the Afghan refugees can be referred to. Once the individual status of the refugees is determined, the UNHCR issues a certificate indicating the 'refugee status' of the individual. Such individuals whose status is determined by the UNHCR in India will have the right to stay in India for a period of one year and receive material assistance from the UNHCR. This certificate is valid for only one year. However, the UNHCR is also permitted to renew the certificates every year if it is necessary to do so. The Government of India retains the power to expel any refugee so determined by the UNHCR in the larger interest of the country. The 16,000 Afghan refugees present in India have the certificates so issued by the UNHCR and continue to receive the renewals as well as material assistance from the office in New Delhi. The UNHCR's office also determines the status of few refugees from West Asia as well as from Africa as their number is very small.

\section{Determination by the State with UNHCR's Assistance}

The UNHCR is also involved in assisting a particular group of refugees by providing them with financial assistance to enable them to reach their final destination and seek refugee status with the appropriate government. The recent arrivals from Tibet into Nepal are received at the reception centres set up in collaboration between the UNHCR and the Central Tibetan Administration, in Nepal. As the status of the Tibetan refugees cannot be determined by the UNHCR, it provides some material assistance at the reception centres to facilitate the onward travel of these refugees to Dharamsala in India. ${ }^{30}$ Thus it is clear that the individual status determination by any body or authority exists only to a very limited extent in this region. This should be taken only as an exception rather than a general rule.

\section{Determination of Refugee Status by UNHCR at the Instance of the Courts}

This type of determination of refugee status is very limited as it permits only those refugees who take the issues to the court of law challenging their detention under the Foreigner's Act. As there is no legal framework in this region relating to the refugees specifically, all the refugees are at times brought under the Foreigner's Act for taking appropriate actions. This is a statute enacted by the British Parliament but adapted by the states concerned after their independence with necessary modifications. Some of the instances where the courts directed the respondents or appellants to approach the UNHCR in New Delhi to seek refugee status are mentioned herebriefly.

In N.D.Pancholiv. State of Punjab, ${ }^{31}$ the Supreme Court of India stayed the deportation order issued against a refugee from Burma (Myanmar) and allowed time to enable the refugee to seek refugee status from the UNHCR office in New Delhi. In Zothansanguliv. State of Manipur $^{32}$ and Bogyiv. UnionofIndia, ${ }^{33}$ the High Court of Gauhati stayed the deportation orders issued against refugees from Burma and allowed them to seek refugee status from the UNHCR office in New Delhi. The court released them from custody toenable them to seek refugee status from the UNHCR's office in New Delhi. The same High Court also gave similar orders in Khy Htoon v. State of Manipur. ${ }^{34}$ Orders were also issued by the same High Court in U. Myat Kayew $\mathcal{E}$ Anotherv. State of Manipur as well. ${ }^{35}$ In this case, the petitioners were from Burma and entered into India illegally. They had taken part in the 'movement for democracy' in Burma and had to flee the country to escape persecution. They voluntarily surrendered to the authorities in India. The court did not insist on sureties for their release as they were total strangers and it would be difficult for them to obtain any local surety. The Punjab and Haryana High court also granted similar relief. ${ }^{36}$

The Supreme Court of India in Dr.Malavika Karlekarv. Union ofIndia ${ }^{37}$ also stayed the deportation order issued against 21 refugees from Burma who were in the Andaman islands and allowed them to seek refugee status with the UNHCR's office in New Delhi. Apart from this, the SupremeCourt also directed that these refugees should not be deported until their applications for refugee status is disposed of by the UNHCR. A careful analysis of the determination of refugee status in the developed countries would reveal the distinct features of the scheme followed in the South Asian region.

\section{Rights and Freedoms of the Refugees}

In determining refugee status, the states in this region have received refugees from other countries and have not discriminated on the basis of race, religion or country of origin. This in effect is also the nature of the obligation undertaken by the parties under Article 3 of the Refugee Convention. The refugees have the freedom to practice their own religion. They have access to the courts in the respective country of asylum as provided under Article 16, Chapter II of the Refugee Convention. The judicial decisions mentioned above would substantiate this point. Within the existing socio-economic environment, the refugees are permitted to have wage earning employment or self-employment as provided under Articles 17 and 18 (Chapter III) of the Convention. Again within the economic resources available in the state, provisions for rationing of essential commodities and at reduced rates are extended to the refugees. The facilities, though not the same, extended to the Sri Lankan Tamil refugees and the Tibetan refugees in India are good examples. ${ }^{38}$ Provision for housing, public education and public relief and assistance as provided under Articles 20,21, 22, and 23 (Chapter IV-Welfare) respectively are also made available to the refugees, subject of course, to the socio-economic conditions. The refugees are provided with freedom of movement, subject to the provisions of existing rules and regulations (Article 26). In the case of Sri Lankan and Tibetan refugees, they were also provided 
with the Identity papers (Article 27). The Sri Lankan refugees who were arriving in 1984 were registered, photographed and issued refugee identity certificates. At the transit camps (Mandapam) refugee families were given cooking and other utensils, clothing, bed sheets and reed mats. After they were transferred to refugee camps, they received a monthly dole of Rupees 110 per head of household and proportionately smaller amounts for each dependant. Essential commodities like rice, sugar and kerosene were available for purchase at subsidised rates. ${ }^{39}$ The Tibetan refugees, who would like to travel abroad were also given the travel document (Article 28) under the Passport Act 1967 as well as the rules made thereunder in 1980 . These rights fall under Chapter V on Administrative measures of the 1951 Refugee Convention.

In reviewing these rights and freedoms of refugees in the South Asian region, the prevailing socio-economic conditions of the asylum states should be kept in mind and should not be compared with the nature and extent of these rights provided to refugees in the developed countries that are parties to the 1951 Refugee Convention or the 1967 Protocol.

Among the refugees, the Tibetan refugees have been enjoying better facilities when compared with the other groups of refugees. The development of five major agricultural settlements in India and several small ones in Sikkim and Bhutan began immediately after their arrival. These settlements received no outside assistance after 1965 but they became self-supporting and emerged as one of the most successful refugee communities in the world. They are being described as a 'model refugee community. ${ }^{30}$ During the early 1960 s, the State of Karnataka came forward to settle 3000 Tibetan refugees on 3000 acres of land and the Government of India extended Rupees 3,784,800 for the purposes of rehabilitation. In 1965 , the Tibetan Industrial Rehabilitation Society was formed. The Government of India helped them to establish a home for the aged and the handicapped, Tibetan schools and cultural institutions. The
Indian Government still bears $25 \%$ of the total rehabilitation expenditure. ${ }^{41}$

Many of the rights provided under the 1951 RefugeeConvention have been granted to the Tibetan refugees to the maximum possible extent, subject of course to the restrictions under various statutes. In this sense, Article 42 of the 1951 Convention and Article VII of 1967 Protocol must be kept in mind. According to these two provisions, the state parties may make reservations on many of the provisions of the Convention and Protocol respectively, relating to the rights and freedoms of the refugees. In considering this interpretation and keeping the economic conditions prevailing in the South Asian countries, what they have provided to the refugees so far is indeed remarkable. In few cases, there is continued assistance forthcoming from UNHCR office itself to the refugees in this region.

Whenever there is reluctance on the part of the states in providing the basic necessities, the refugees have been successful in getting them remedied through legal initiatives taken directly by them or through the initiatives taken by the NGOs on their behalf. Some of these developments are briefly explained in this article, relating to the role of the UNHCR and other institutions in this region.

\section{Involvement of Developed Countries in this Region}

The international community as a whole and the developed countries in particular have been involved in the refugee crisis of this region in one form or the other. Apart from funding development projects in the countries of the South Asian region, some of the developed countries have also liberally contributed to refugee relief in South Asia, either in the form of financial assistance or in kind. Cholera vaccine, tents, oil, rice, sugar, milk, vitamin tablets, clothing, other medicines and food grains have been contributed by these countries directly. Indirectly, they have also been contributing to the funds of the UNHCR from which the money is also spent on the South Asian countries for various activities related to refugees in the region.
To illustrate the nature of assistance, reference may be made to the 1971 crisis when an estimated 10 million refugees came to India from East Pakistan (now Bangladesh). 48 countries contributed in cash or in kind, by and large for the relief operations in India, to the extent of U.S $\$ 203,612,281$. The contributions made by the countries like Canada, Australia, Belgium, France, GDR, FRG, Netherlands, Norway, Sweden, Switzerland, U.S.S.R, United Kingdom and the U.S.A, including the EEC was totalledU.S $\$ 193,948,535$. The contributions made by the U.S alone stood at U.S. $\$ 89,257,000$, almost $44 \%$ of the total refugee aid to India. ${ }^{42}$

Although these figures indicate the nature of international concern and burden sharing, it was far below the requirements of the situation. The total direct cost to India caused by the refugee influx was estimated to be around U.S. $\$ 800$ million up to March 31,1971 and more than that for the subsequent period of three months i.e. up to June 30 , 1971. It was estimated that maintaining the refugees for one year would directly cost India U.S \$ 500 million more than the net foreign aid it received from all western nations. ${ }^{43}$ Senator Edward M. Kennedy described the nature of the assistance extended by the western countries in his report on ' $[t]$ he Crisis in South Asia'. According to him 'The international community's response to the refugees has been unconscionably lethargic and wholly inadequate. It is characterised by little sense of urgency and a low priority of concern for this tide of human misery unequalled in modern times'. In yet another context, he commented that ' $[w]$ hen we realise that India faces the prospect of a budget for refugee relief totalling $\$ 500$ million to $\$ 1$ billion over this coming year alone, we realise how little the outside world is really doing, and how paltry the American contribution is comparatively. ${ }^{.44}$

The international community has been also attempting to find durable solutions to some of the refugee problems in the South Asian region by telling the countries concerned to start a meaningful dialogue to resolve the conflicts relating to the flow of refugees. For ex- 
ample, the European Parliament has unanimously adopted a resolution calling on Bhutan to take back the refugees from Nepal and safeguard the rights of the minorities on its territory. The European Parliament had also called on India to release hundreds of Bhutanese refugees who have been arrested while they were trying to reach Bhutan via India to press their demands for human rights and repatriation. ${ }^{45}$ The United Kingdom blamed the Sri Lankan Government for the Jaffna exodus. ${ }^{46}$ The European Union in its first substantive international reaction to the current crisis in Sri Lanka has called on the Government as well as the Liberation Tigers of Tamil Eelam (LTTE) to stop fighting and start negotiations with a view to securing a peaceful resolution to the Sri Lankan conflict that has displaced a large number of civilians both within Sri Lanka and to other countries. ${ }^{47}$

Many of the developed countries have granted asylum to refugees coming from the countries in South Asia. ${ }^{48}$ Canada has accepted the majority of the Tamil refugees from Sri Lanka in the last fifteen years. However, some of the northern states like U.K, have increasingly adopted restrictive measures in the recent past. These developments should be kept in mind in appreciating the contributions made by the developed countries to the refugees coming from the countries in South Asia or remaining within that region. However, when compared to the number of refugees protected within South Asia, the number of refugees coming from South Asian region to these developed countries is relatively less.

\section{Role of UNHCR and Other Institutions}

Five counties in this region, i.e. Bangladesh, India, Nepal, Pakistan and Sri Lanka, have the UNHCR offices established in their territories. In some of the countries, the UNHCR also has an additional branch to look after a specific function assigned to it. These offices are actively involved in a series of activities, except the determination of the status of refugees.. The UNHCR office is actively involved in the assistance programmes in Bangladesh, Nepal and Sri Lanka. Apart from this, the UNHCR was involved in the repatriation of the Rohingya refugees back to Myanmar. Similarly, the Extension office of UNHCR established in Madras, Tamil $\mathrm{Nadu}$, also monitored the voluntariness in the repatriation of Sri Lankan Tamil refugees. The office of UNHCR provided vocational training to the $\mathrm{Ti}$ betan refugees and came to be established in India in 1969 based on a Memorandum of Understanding signed between India and UNHCR. A similar exercise was also carried out in Nepal. In 1971, the UNHCR was designated by the U.N Secretary General as the focal point to co-ordinate the relief operations and assistance coming from various countries and organisations during the largest refugee influx.

In an attempt to resolve the issues relating to the Bhutanese refugees in Nepal, and other related issues, the High Commissioner Mrs. Ogata undertook a nine-day trip to the Indian subcontinent during May 2000. During her first visit to the region, Mrs. Ogata met with the Kings of Bhutan and Nepal and other top leaders of these two countries. Both Nepal and Bhutan have accepted the High Commissioner's proposal to use UNHCR's refugee database as a reference for joint verification. The High Commissioner believes that the visit has been timely and has created a momentum which needs to be maintained. She also met with the external affairs and law ministers of India and obtained the support of India for UNHCR's efforts to resolve the Bhutanese refugee problem. ${ }^{49}$

Thus, the countries in this region, though not parties to the 1951 Refugee Convention or the 1967 Protocol, have permitted the establishment of the offices of the UNHCR and extended full co-operation to those offices. The presence of three members from the South Asian region (Bangladesh, India and Pakistan) on the Executive Committee of the UNHCR indicates the nature of the relationship in working together for the protection of the refugees in this region as well. The reliance on the office of the UNHCR by the judiciary in the recent past, as indicated above, has only strengthened this understanding and relationship. In a different situation, the High Court of Madras allowed the UNHCR office to verify the voluntariness present in the repatriation of Tamil refugees back to Sri Lanka. ${ }^{50}$

Apart from this, the National Human Rights Commission (NHRC) established under the Protection of Human Rights Act, 1993 in India has also contributed significantly to the protection of refugees in India. The NHRC had issued directions to the stategovernments of Tamil Nadu, Arunachal Pradesh and Mizoram to provide immediate medical treatment to some of the Sri Lankan refugees and to take all possible measures to ensure the safety of lives and properties of the Chakma refugees respectively. ${ }^{51}$ The NHRC had also brought a challenge before the Supreme Court of India seeking to protect the Chakma Refugees present in the state of Arunchal Pradesh. ${ }^{52}$

Even with a very limited exposure to the refugee regime, an NGO had come forward to protect the basic rights and needs of the refugee children in the State of Karnataka. In Digvijay Mote v. Government of India and Others, ${ }^{53}$ the Petitioner successfully brought a challenge before the High Court of Karnataka to get appropriate relief for the 250 refugee children present in a boarding school. Based on this, immediate humanitarian assistance to the school was provided by the government. This clearly indicates the developments that are taking place in some of the countries in South Asia (India particularly) in protecting the rights of the refugees. In People's Union for Civil Liberties v. Union of India $^{54}$ the Supreme Court of India held that the customary principles of international law is a part of the domestic law of the land as long as these principles are not inconsistent with the existing laws in the domestic sphere. The court also observed that ' $[\mathrm{I}]$ nternational law is now more focused on individuals than ever before'. The High Courts in India have also issued a number of orders in an attempt to protect the rights and freedoms of the refugees. ${ }^{55}$ The recently concluded Judicial Colloquium 
held in New Delhi during November 1999 brought a number of judges and senior lawyers together for the first time and is likely to contribute to this trend in the future for better protection of refugees, particularly in India.

\section{The Prospects for Refugee Law}

The states in this region have adapted the British legislation passed prior to independence, like the Foreigners Act, Registration of Foreigners Act and the Passport Act. These laws provide the required balancing between refugee protection and national interest. These laws are being put to use on a regular basis to remove 'unwanted' people from the territory of the state. Apart from this the non-existence of any specific refugee legislation has also contributed to the differential treatment of refugees from time to time.

There seems to be a predominant opinion among the governments in the South Asian region that the Convention of 1951 was drafted in a different political environment and that there is every need to review the Convention. The speech delivered by Ms. Arundathi Ghosh, India's permanent representative to the U.N. at the EXCOM very clearly indicates the same..$^{56}$ Although the states have reposed confidence in the UNHCR, they are hesitant, for one reason or the other, to ratify the Convention or the Protocol relating to the Status of Refugees. However, such a review, if and when taken up should concentrate on specific spheres like evolving more meaningful burden sharing, specific durable solutions, more meaningful international obligations, and accountability of refugee producing states if they are primarily responsible for sending the refugees to other states within the existing framework. This review is to be undertaken not for having wider acceptance but for making the instrument as well as institution created thereunder to be more meaningful and effective. Proposals to make UNHCR a permanent specialised agency should also be pursued.

Although the provisions of the respective Constitutions are invoked in an attempt to protect the refugees and their rights, that may not provide a complete framework. Unless there is international pressure coupled with public opinion in these states, getting the necessary legal framework is a difficult proposition. At the same time, it is also not necessary to have a legal framework to extend protection to the refugees. The South Asian countries have proved that by accommodating a large number of refugees. In this context, developing a legal framework for the protection of refugees by the states may have very little effect. Yet, the arbitrariness present in treating different groups differently can be prevented only if a law relating to refugees is present in these countries.

The initiative taken by the Eminent Persons Group from Bangladesh, India, Nepal, Pakistan and Sri Lanka in developing a draft regional declaration as well as a Model National Law relating to the refugees is to be appreciated. The former Chief Justice of India, Justice P.N.Bhagwati, has recently presented the revised draft to the Ministry of Law and Justice in India for consideration. ${ }^{57}$ This must be taken to logical conclusions with the efforts taken by UNHCR and other international bodies. The efforts taken by Asian-African legal Consultative Committee (AALCC), both in the areas of human rights and refugees should also be projected effectively to achieve this end. The other existing regional forum, South Asian Association for Regional Co-operation could also be the platform to project this view. In getting the regional declaration accepted by all the states. Already the efforts taken by SAARCLAW in this regard needs to be pursued. Efforts taken by other institutions, NGOs and bodies like LAW ASIA should be relied upon to achieve the desired objective.

The present trend in favour of globalisation and economic liberalisation can be effectively utilised by adopting a two dimensional approach. In the first place, international efforts should be concentrated on genuine development programmes including institutional and human resource capacity building. In the second place, such in- ternational efforts should focus on facilitating the legal framework and institutions to be established for the protection of human rights. This could address both the economic policies and social policies of these countries that would go a long way in preventing outward flows as well as tolerance towards inward flows of refugees. This would also facilitate new approaches to refugee protection in the South Asian context. This approach can also contribute both to the regional and global opinion on contentious issues that could be effectively used against the states that violate the internationally accepted norms. Taken together, there is an excellent and conducive atmosphere in the South Asian region more than ever before for evolving a legal framework in the protection of the refugees.

\section{The Comparison}

Against this backdrop, comparing two incomparables is a difficult task. However, within the framework provided, a general observation comparing the Northern perspective with that of the Southern perspective can be attempted.

Some of the important distinctions between the Northern approach and Southern approach to the refugee problem would include the following. In the first place, mention must be made to the determination process. While the developed countries engage in individual determination by and large, the countries in South Asia engage in the group determination of refugees. In this process of determination, the developed countries have established a variety of administrative, quasi-judicial and appellate mechanisms while the countries in South Asia have not. The developed countries have enacted appropriate domestic legislation to give effect to the international obligations they have undertaken under the 1951 Refugee Convention and/or the 1967 Protocol, while there is no such legal framework in the South Asian countries. While the South Asian countries rely very heavily on the bilateral approach to resolve refugee crises, there is no such reliance placed on it by the developed countries. Again the South Asian countries have at- 
tempted to resolve the problems of 'statelessness' by accommodating large numbers of people of their origin and by providing citizenship to them. The emergence of joint responsibility in this regard can also be seen in that process of resolving the issues arising out of population movements. The willingness on the part of India in according citizenship to 338,000 stateless persons from Sri Lanka and the efforts of the Sri Lankan Government to accommodate the rest of them is to be appreciated. The developed countries in resolving some of the refugee problems have also taken up such joint responsibility. Thousands of refugees from Burma, as indicated earlier, have also been assimilated in India without allowing them to create a refugee problem elsewhere. As far as the rights and liberties of the refugees are concerned, there seems to be a wide gap between these two schemes. The developed countries have provided a number of rights and liberties as well as extended a number of welfare measures when compared to the countries in South Asia.

When the systems present in these two groups of states, one can also identify certain similarities. Both the schemes permit the judiciary to resolve certain specific questions of law arising out of their determination, removal or in safeguarding their rights and liberties. There seems to be an active role placed by the human rights institutions, directly or indirectly, in both groups of countries. An increased number of NGOs are taking keen interest in the protection of refugees. Finally, there is an ever increasing awareness arising out of the 'Human Rights' concept that contribute to better protection of refugees throughout the world today.

To conclude, it may be observed that the purpose or the object of such a comparison is not to find out who is doing the best in protection of refugees. On the contrary, keeping the huge population, conditions of poverty, illiteracy and the like in the developing countries, the developed countries have a definite positive role to play. Apart from the funding for development extended to the developing countries, a constant effort to edu- cate the people as well as training of officials in these countries in the areas of human rights, assisting them in setting up institutions and training of the judges at all levels would go a long way in the protection of human rights of every individual in this world. The primary task for the developed countries would be to assist the developing countries to establish the appropriate legal framework in the protection of the refugees. To sustain this effort, an attempt must also be made to establish the necessary links at two different levels, with the academic institutions of higher learning in these countries for a constant and ongoing interaction with those institutions. Networking of educational institutions within these developing countries in the first place and then linking them with the institutions in the developed countries would certainly enhance the pace of establishing a human rights culture in the developing countries in South Asia. Reliance on a comparative analysis coupled with the perspective on human rights and refugee protection would certainly promote best practices in both the Northern and Southern countries in the years to come.

\section{Notes}

1. Guy S.Goodwin Gill, The Refugee in International Law, 2nd Edition (Oxford: Clarendon Press, 1996) at 12 note 48. Also see IvorC. Jackson, The Refugee Concept in Group Situations, (The Hague, Martinus Nijhoff Publishers, 1999) at 62.

2. Pia Oberoi, 'Regional Initiatives on Refugee Protection in South Asia', (1999) 11I Journal of Refugee Law.1 at 193.

3. Amitav Acharya and David B. Dewitt, Fiscal Burden Sharing, James C. Hathaway, Ed., Reconceiving International Refugee Law, (The Hague: Martinus Nijhoff Publishers, 1997) at 126.

4. G.A Res. 52/104, 12 December 1997. Through this Resolution, the term of office of the UNHCR was extended by another five years with effect from 1 January 1999. Through this Resolution it was alsodecided to review the arrangements for the Office of UNHCR with a view to determining whether the office should be continued beyond 31 December 2003.

5. Justice V.R.Krishna Iyer, The Legal Saga for Refugees and Humanitarian Odyssey, Bulletin on International Humanitarian
Law and Refugee Law, Vol.2, No. 2(A), p.313.

6. VititMuntarbhorn, The Status of Refugees in Asia (Oxford:Clarendon Press, 1992) at 52 .

7. The developments during the 1947 exodus as a result of the establishment of two independent Dominions of India and Pakistan must be kept in mind. An estimated 15 to 20 million people have crossed the newly drawn international boundaries. During the 1971 war between India and Pakistan, 10 million people have taken refuge in India with delayed assistance from international community. For details on this issue, see Crisis in South Asia, A Report by Senator Edward M.Kennedy, Committee on the Judiciary, United States Senate, November 1, 1971.

8. Myron Weiner, Rejected Peoples and Unwanted Migrants in South Asia, Economic and Political Weekly, Vol.XXVIII, No.34, August 21, 1993, at 1745.

9. The State of World Refugees, 1997-98, UNHCR, Geneva.

10. World Refugee Survey, 2000, U.S. Committee for Refugees, at 3.

11. Lok Raj Baral and S.D.Muni, Eds., Refugees and Regional Security in South Asia (Delhi: Konark Publishers Private Limited, 1996) at 10.

12. Ibid., at 195.

13. World Refugee Survey, 2000, U.S Committee for Refugees, at 3.

14. The Hindu, dated January 6, 1991.

15. The Statesman, (Calcutta Edition), dated June 2, 1994.

16. Crisis in South Asia, A Report by Senator Edward M.Kennedy, U.S Senate Committee on the Judiciary, November 1 , 1971 at 5 .

17. Nicole Ball, Regional Conflicts and the International System, (ISIO Monographs, First Series, Number Nine, Institute for the Study of International Organisation, University of Sussex, 1974) at 29.

18. UNHCR, A Story of Anguish and Action, Geneva, 1972 at 79.

19. The World Refugee Survey, 2000, U.S Committee for Refugees at 3 indicates that 110,000 Bhutanese are in Nepal while India hosts 15,000 .

20. The Week, Vol.17, No.40, September 19, 1999 at 20.

21. Supra, n.6 at 10 and 23.

22. Ibid., at 18-19.

23. Mahendra P. Lama, Refugee Situation in South Asia: Critical Issues in Perspective,(1999) 3 Bulletin on International 
Humanitarian Law and Refugee Law.1, at 95.

24. World Refugee Survey, 2000, U.S Committee for Refugees, at 3 .

25. Article 2 of the Statute provides that "The work of the High Commissioner shall be of an entirely non-political character; it shall be humanitarian and social and shall relate, as a rule, to groups and categories of refugees.'

26. Ivor C.Jackson, The Refugee Concept in Group Situations, (The Hague: Martinus Nijhoff Publishers, 1999) at 314.

27. Asian Recorder, 1992, March 25-31, p.22211.

28. Supra, n.12 at 6.

29. The Hindu, dated July 6, 1990.

30. World Refugee Survey, 1999, U.S. Committee for Refugees at 128. The World Refugee Survey, 2000, at168, relying on the UNHCR report, states that during 1999 a total 2182 Tibetans entered Nepal for onward journey to India.

31. W.P.No. 243/88, Supreme Court of India. 32. C.R.No. 981/89, Guahati High Court.

33.. C.R No.1847/89, Gauhati High Court.

34. W.P No. 515/90, Gauhati High Court.

35. C.R.No. 516/91, Gauhati High Court.
36. W.P.No. 658/97, Punjab \& Haryana High Court.

37. W.P(Criminal) No. 583/92, Supreme Court of India.

38. World Refugee Survey, 1999, U.S. Committee for Refugees, at 128-129.

39. B.S.Chimni, The Legal Condition of Refugees in India, (1994) 7 Journal of Refugee Studies 4 at 378-401.

40. Supra, n.8 at 81-84.

41. Tibet in Exile, 1969:3 (c.f Asha Hans and Astri Suhrke, Responsibility Sharing, James C.Hathaway, Ed., 'Reconciling International Refugee Law', (The Hague: Martinus Nijhoff Publishers, 1997) at 83110.

42. Supra, n.12 at 38-41.

43. Ibid., at 34-35.

44. Ibid., at 34 and 41.

45. Asian Recorder, April 15-21, 1996 , p.25560.

46. Asian Recorder, February 5-11, 1996 , p.25404.

47. The Hindu, dated May 17, 2000.

48. For details as to the country of origin, country of asylum and the number of refugees admitted, please see the Statistics provided by UNHCR for the year 1998 <http://www.unhcr.ch/statist/98/ tab5_10.htm>.

49. <http://www.unhcr.ch/news/media/ media.htm $>$.

50. P.Nedumaran and Dr.Ramdoss v. Government of India and Others, W.P.12343/ 1992, Madras High Court.

51. Human Rights Newsletter, National Human RightsCommission, Vol.1, No.2, November 1994, at 3-6.

52. National Human Rights Commission v State of Arunachal Pradesh, (1996) 1 SCC 742.

53. W.A.No. 354/1994, Karnataka High Court.

54. (1997) 3 SCC 301.

55. K.A.Habib v. Union of India, (1998 (2) Gujarat Law Herald 1005). In this case, the Gujarat High Court even went to the extent of reading the principle of non-refoulement as part of Article 21 of the Indian Constitution that guarantees to every person the right to life and personal liberty and held that the two refugees from Iraq could not besent back to that country because of their fear of persecution.

56. Deccan Herald, dated October 17, 1997

57. The Deccan Herald, dated May 8, 2000 व

\section{Legitimate and Illegitimate Discrimination: New Issues in Migration}

\section{Edited by Howard Adelman}

Toronto: Yorkl Lanes Press, $1995,1 S B N$ 1-55014-238-0; 287 pages, indered; \$22.95

Freedom of movement: If the members of astate are forced to flee, the legitmacy of that government is questionable. On the other hand, if members cannot or must leave, again the government is not democratically legitimate.

Immigration control: While limiting access and determining who may or may not become members of a sovereign state remains a legitimate prerogative of the state, the criteria, rules and processes for doing so must be compatible with its characteras a democratic state.

Legitimate and Mlegitmate Diserimination. New Issues in Migration, edited by Professor Howard Adelman, deals with the question of legitimacy with ceses studites from the Developing World, Europe, Australia, the United States, and Cenada.

\section{Covinumons:}

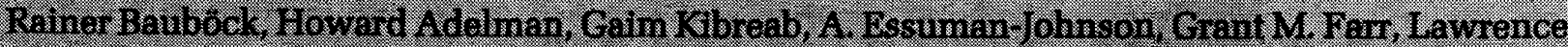
Lan, Oscar Schrappa-Pletra. Tomas Hammar, Fród6ric Thborghion (in French), Iois Foster, and Arthur C. Helton.

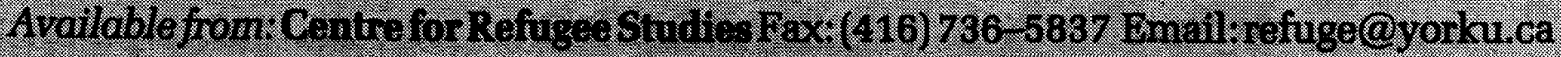

